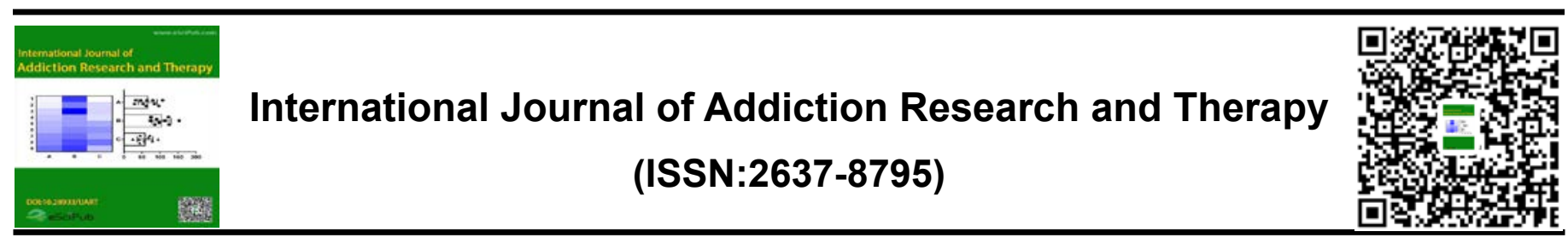

\title{
MAGUEREZ ARCH AS A METHODOLOGY FOR APPLICABILITY OF ACTIONS IN ADHESION TO ALCOHOL TREATMENT
}

\section{Carla Suzana Balbino da Silva Miranda ${ }^{1 *}$, Arely de Macêdo Bona², Flávia Alessandra Bezerra Furtado ${ }^{3}$, Márcia Vannusa Vieira ${ }^{4}$, Maria Jamisse de Araújo Oliveira ${ }^{5}$; Vanessa de Morais Braga6; \\ ${ }^{1 *}$ Mestranda na Universidade Estadual do Ceará (UECE), ${ }^{2}$ Mestranda UECE; ${ }^{3}$ Mestranda UECE; ${ }^{4}$ Mestranda UECE; ${ }^{5}$ Mestranda UECE; ${ }^{6}$ Mestranda UECE}

\begin{abstract}
Introduction The active methodology is an educational conception that stimulates critical-reflexive teaching-learning processes. Objective to apply the Arco de Maguerez in the Jardim Oasis community, in the municipality of Iguatu-CE. Methodology The first method was applied to the Hanlon method, in which priorities were established, based on the criteria of magnitude, severity, effectiveness and feasibility. Each criterion was analyzed using nu-merical score scores: magnitude (1-10); severity (1-10), effectiveness (0.5-1.5) and feasibil-ity (0 or 1$)$. It was through the observational analysis that the problematization "difficulty in adhering to the treatment of alcoholism" was highlighted. As a methodological framework, he used the Maguerez Arch based on "five steps": observation of reality; key points of the problem; theorization; hypotheses of solution; application of action in reality. Results First Step - Observation of Concrete Reality. Second Step - Determination of Key Posts Third Step - Theorizing: There is a consensus in the literature on the low adherence rate of de-pendents, the dropout rates are generally above $50 \%$. The literature found that more than $50 \%$ of patients evade in the first month. Fourth Step - Solution Hypotheses: Establish Links; inform; use harm reduction policy. Step Five - Application to Reality; Action plans to improve the problem in the reference territory. Conclusion It was understood that despite being a pedagogical instrument focused on the teaching - learning process, it can be fully applied in the daily routine of health services, starting from a social reality up to the mo-ment of effectiv
\end{abstract}

\section{*Correspondence to Author:}

Carla Suzana Balbino da Silva Miranda

Mestranda na Universidade Estadual do Ceará (UECE)

How to cite this article:

Carla Suzana Balbino da Silva Miranda, Arely de Macêdo Bona, Flávia Alessandra Bezerra Furtado, Márcia Vannusa Vieira, Maria Jamisse de Araújo Oliveira; Vanessa de Morais Braga.MAGUEREZ ARCH AS A METHODOLOGY FOR APPLICABILITY OF ACTIONS IN ADHESION TO ALCOHOL TREATMENT.International Journal of Addiction Research and Therapy, 2020, 3:16

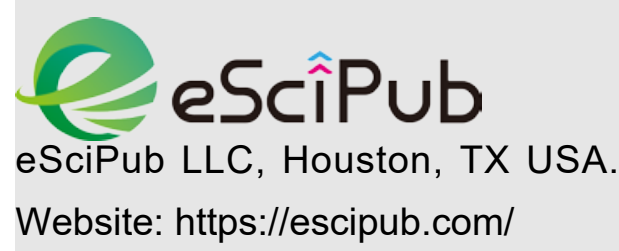




\section{INTRODUCTION}

The active methodology is an educational conception that stimulates critical-reflexive teaching-learning processes, in which the student participates and commits to their learning. The method proposes the elaboration of teaching situations that promote a critical approach of the student with the reality and organization of the hypothetical solutions most appropriate to the situation and the application of these solutions ${ }^{1}$.

Among the many ways to work with active methodology, the Maguerez Arch presents itself as a teaching strategy used with a focus on problematization. The arc method developed by Charles Maguerez and adapted by DiazBordenave, provides a space for discussion and socialization of themes close to the reality of the subjects.

Teaching professionals need to adopt new attitudes regarding their teaching-learning relationship with the student, being directly influenced by social demands. Based on this premise, the present study aimed to apply the Maguerez Arch in the Jardim Oasis community, in the municipality of Iguatu-CE, where the problematization was listed: difficulty in adhering to the treatment of alcoholism.

\section{METHODOLOGY}

A management wheel was held by six students of the master's degree in health education at the State University of Ceará (UECE), together with the work team of the Family Health Strategy (ESF) of Jardim Oásis. This community is located in the city of Iguatu, center-south region of Ceará. The population of the Jardim Oasis community is estimated at 4,087 people, equivalent to $3.9 \%$ of the total population of the city of Iguatu. After this discussion, problems were selected that the team considered more eminent and that needed more immediate actions. So that we could elect a problem among the five, we applied the Hanlon Method, in which the priorities were established, starting from the criteria of magnitude (dimension that the problem assumes for the population), severity (severity of the problem), effectiveness (ease resolution) and feasibility (feasibility of intervention action). Each criterion was analyzed using numerical score scores: magnitude (1-10); severity (1-10), effectiveness (0.5-1.5) and feasibility $(0$ or 1$)$. It was through the observational analysis that the problematization "difficulty in adhering to the treatment of alcoholism" was highlighted. As methodological framework, he used the Maguerez Arc based on "five steps"2: observation of reality; key points of the problem; theorization; hypotheses of solution; application of action in reality (Figure 1).

\section{DISCUSSION AND RESULTS \\ STEPS OF MAGUEREZ ARCH \\ Step One - Observing Concrete Reality}

For observation and survey of problems of the territory, a management wheel was held with the team, and from the discussion generated the socialization of the main problems present and directly affecting the community, which stood out: alcoholism, mental disorders, poor infrastructure public roads, teenage pregnancy, polluted lagoon, population above the limit recommended by the Ministry of Health, worker mental health, friction in relationships between population and health workers, insufficient provision of examinations and specialized consultations and obesity. After this discussion were selected five problems that the team considered more eminent and that needed more immediate actions, they were: alcoholism, mental disorders, teenage pregnancy, population over the limit, health of the worker. Alcoholism was considered by the team the most urgent problem to be worked in the territory. Thus, the following problem was delimited in the observatory analysis: difficulty of adherence of alcoholics from Jardim Oasis to treatment.

\section{Step Two - Determining Key Points}

At this stage, the students of the master's degree together with the FHS team researched and reflected on the possible causes of the existence 
of the problem under study, which are essential for the resolution of the proposed problem. ; community culture; financial difficulties; television advertising stimulus; lack of a good job; lack of values; lack of social recognition; violence; problem leakage; habit / conditioned behavior; lack of self-esteem; lack of prospects for the future; psychological weakness; difficulty expressing yourself.

\section{Step Three - Theorizing}

Alcoholism, also known as "alcohol dependence syndrome", [...] has several negative effects on physical and mental health, which most often cause serious harm, whether work, family or social, and which are related to social exclusion, traffic accidents, aggressive behaviors. It can also cause not only personal and family losses, but also losses in the professional environment, such as decreased productivity ${ }^{3}$

Research conducted in 11 FHS in a city in southeastern Brazil, the factors most related to alcohol abuse are: family factors or problems / unstructured family; community culture; financial difficulties; peer stimuli; Stimulation of television advertising; lack of a good job; lack of leisure alternatives; lack of values; lack of social recognition; violence; problem leakage; conditioned behavior; lack of self-esteem; lack of prospects for the future; psychological weakness; difficulty in expressing oneself 4 .

Consensus in the literature is the low rate of adherence by dependents, the dropout rates are generally greater than $50 \%$. The literature found that more than $50 \%$ of patients evade in the first mont ${ }^{5}$.

\section{Fourth Step - Solution Assumptions}

- Establish the links (humanized reception) between the multiprofessional health team and users emerges the structuring pillar of treatment;

- Inform / empower the family about alcoholism through health education, so the family tends to support users in treatment;

- Use the Harm Reduction Policy to make a commitment to public health and human rights;

- When there is integration / articulation between the intersectoral network, there is alignment of treatment-oriented conducts;

\section{Step Five - Applying to Reality}

Figure 1 - Action plans to improve the problem in the reference territory

\begin{tabular}{|l|l|l|l|l|l|}
\hline ACTION & METHODOLOGY & PARTNERS & OBJECTIVE & EVALUATION & PERIOD \\
\hline WHAT TO DO & HOW TO MAKE & WHO TO DO & WITH WHOM & WHAT TIME & AT RESULTS \\
\hline $\begin{array}{l}\text { Active } \\
\text { Search }\end{array}$ & Home visits & $\begin{array}{l}\text { With } \\
\text { professional } \\
\text { community } \\
\text { health agents }\end{array}$ & $\begin{array}{l}\text { Know and } \\
\text { establish first } \\
\text { contact }\end{array}$ & 3 months & $\begin{array}{l}\text { Conversation } \\
\text { Wheel with } \\
\text { Community } \\
\text { Agents }\end{array}$ \\
\hline $\begin{array}{l}\text { Raise } \\
\text { awareness of } \\
\text { treatment } \\
\text { adherence }\end{array}$ & $\begin{array}{l}\text { Wheels of talk about } \\
\text { psychoactive } \\
\text { substances and use / } \\
\text { abuse, focusing on } \\
\text { alcohol }\end{array}$ & $\begin{array}{l}\text { Health } \\
\text { Professionals } \\
\text { AB, NASF / } \\
\text { CAPS ad }\end{array}$ & $\begin{array}{l}\text { Clarify to users } \\
\text { and family } \\
\text { members that } \\
\text { substance } \\
\text { dependence is a } \\
\text { disease }\end{array}$ & 6 months & $\begin{array}{l}\text { Number of } \\
\text { users seeking } \\
\text { specialized } \\
\text { network } \\
\text { treatment }\end{array}$ \\
\hline $\begin{array}{l}\text { Use of Harm } \\
\text { Reduction } \\
\text { Policy }\end{array}$ & $\begin{array}{l}\text { Referral to } \\
\text { specialized care unit, } \\
\text { Psychosocial Care } \\
\text { Center Alcohol and } \\
\text { Other Drugs - CAPS } \\
\text { ad. }\end{array}$ & $\begin{array}{l}\text { Peamage caused } \\
\text { (CAPS ad) } \\
\text { bufsychoactive } \\
\text { substance use, } \\
\text { whether social, } \\
\text { economic and / } \\
\text { or family }\end{array}$ & 1 year & $\begin{array}{l}\text { Semi-structured } \\
\text { questionnaire }\end{array}$ \\
\hline
\end{tabular}




\section{FINAL CONSIDERATIONS}

The use of the "Arco de Maguerez" teaching strategy, based on the problematization methodology, proved to be essential, dynamic and effective for the survey of real community problems, aiming at the practice of actionreflection-action. Although it is a pedagogical instrument focused on the teaching - learning process, it can be fully applied in the daily routine of health services, starting from a social reality up to the moment of effective interventions.

\section{REFERÊNCE}

1. DIAZ-BORDENAVE; J. E. Estratégias de ensinoaprendizagem. 28 ed. Petrópolis: Vozes; 2007

2. KLEIN, Vanessa; SMANIOTTO BARIN, Cláudia. Arco de Maguerez como Estruturador do Ensino de Química na Modalidade EJA. CIET:EnPED, [S.I.], maio 2018. ISSN 2316-8722. Disponível em:

<http://cietenped.ufscar.br/submissao/index.php/ 2018/article/view/105>. Acesso em: 18/08/2019.

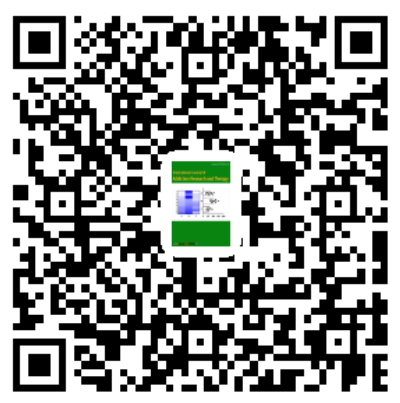

3. CISA. Àlcool e a Saúde dos Brasileiros: panorama 2019. Disponível em: <http://www.cisa.org.br/upload/Panorama_Alcool Saude_CISA2019.pdf> Acesso em: 18/08/2019.

4. SOUZA, L. G. S; MENANDRO, M. C. S; MENANDRO, P. R. M. O alcoolismo, suas causas e tratamento nas representações sociais de profissionais de Saúde da Família. Rev de Saúde Coletiva, 2015; 25 (4): 1335-1360.

5. SURJON J, PILLON S, LARAJEIRA R. O que acontece com os pacientes dependentes de álcool e drogas que desaparecem das primeiras consultas? J Bras Psiquiatr . 2000;49(8):571-5. 